\title{
PERJANJIAN BAKU KREDIT PEMILIKAN RUMAH (KPR) DIHUBUNGKAN DENGAN PASAL 45 UNDANG-UNDANG NOMOR 8 TAHUN 1999 TENTANG PERLINDUNGAN KONSUMEN
}

\author{
Aji Halim Rahman ${ }^{1}$ \\ Ajihalimrahman09051995@gmail.com
}

\begin{abstract}
ABSTRAK
Rumah merupakan kebutuhan primer bagi sebagian besar keluarga, baik yang tinggal di pedesaan maupun di perkotaan yang merupakan suatu kebutuhan primer. Pemenuhan kebutuhan primer tersebut, tidak dapat dipenuhi oleh semua orang untuk membeli secara tunai. karenanya diperlukan suatu lembaga keuangan untuk memberikan bantuan dana dalam bentuk penyaluran kredit terutama dalam Kredit Pemilikan Rumah (KPR), Permasalahan dalam bisnis perumahan yang sering muncul adalah ketentuan mengenai pernyataan dan persetujuan untuk menerima segala persyaratan yang tercantum dalam surat pemesanan, yang sering disebut perjanjian baku atau klausula baku.

Metode penelitian yang digunakan dalam penelitian ini adalah deskriptif analisis dan pendekatan yang digunakan dalam penelitian ini adalah pendekatan yuridis normatif, yaitu dengan mengkaji atau menganalisis data sekunder yang berupa bahan-bahan hukum sekunder dengan memahami hukum sebagai perangkat peraturan atau norma-norma positif di dalam sistem perundangundangan yang mengatur mengenai permasalahan dalam penelitian ini. Setelah data sekunder dan primer terkumpul, kemudian diadakan analisis secara kualitatif.

Berdasarkan hasil analisis data, disimpulkan bahwa konsumen merasa dirugikan dapat menggugat pelaku usaha. Begitu pula menurut Pasal 45 UUPK setiap konsumen yang dirugikan dapat menggugat pelaku usaha melalui lembaga yang bertugas menyelesaikan sengketa antara konsumen dan pelaku usaha atau melalui peradilan yang berada di lingkungan peradilan umum. Posisi konsumen pada umumnya lemah dibandingkan dengan pelaku usaha Hal ini berkaitan dengan tingkat kesadaran akan haknya, kemampuan financial dan daya tawar yang rendah. Tata hukum harus memposisikan pada tempat yang adil dimana hubungan konsumen dan pelaku usaha berada pada kedudukan yang saling menghendaki dan mempunyai tingkat ketergantungan yang cukup tinggi satu dengan yang lain.
\end{abstract}

Kata Kunci: Perjanjian Baku, Rumah, Perlindungan Konsumen

\footnotetext{
${ }^{1}$ Dosen FH Universitas Majalengka
} 
PRESUMPTION of LAW

Fakultas Hukum Universitas Majalengka

Volume 2 Nomor 2 Oktober 2020

\section{A. Latar Belakang}

Pembangunan ekonomi Indonesia tidak bisa lepas dari dasar falsafah yang melandasi kegiatan bernegara dan berbangsa, yaitu Pancasila dan Undang-Undang Dasar 1945 (UUD 1945). Dasar pembangunan ekonomi di Indonesia diterjemahkan dalam Pasal 33 UUD 1945 Amandemen IV yang menjadi landasan penyelenggaraan ekonomi nasional yang menyatakan, bahwa perekonomian disusun dan dikembangkan sebagai usaha bersama seluruh rakyat secara berkelanjutan berdasar asas keadilan, efisiensi dan demokrasi ekonomi untuk mewujudkan kemakmuran, kesejahteraan dan keadilan sosial bagi seluruh rakyat. ${ }^{2}$ Di Indonesia kesejahteraan masyarakat erat kaitannya dengan kebutuhan pokok atau primer. Kebutuhan pokok tersebut merupakan kebutuhan yang sangat mendasar, antara lain kebutuhan akan pangan, sandang dan papan. Melihat perkembangan populasi penduduk Indonesia saat ini yang semakin bertambah, maka kebutuhan primer masyarakatpun menjadi semakin tinggi, salah satunya adalah kebutuhan akan papan atau rumah.

Berdasarkan Pasal 1 ayat (1) Undang-Undang Nomor 4 Tahun 1992 tentang Perumahan dan Pemukiman, ditentukan bahwa rumah adalah bangunan yang berfungsi sebagai tempat tinggal dan hunian bagi pembinaan keluarga.Kebutuhan akan perumahan pada masa sekarang ini merupakan masalah nasional, terutama di daerah perkotaan, yang harus dicarikan solusinya baik oleh pemerintah bersama-sama dengan masyaratkat selaku pengusaha maupun selaku konsumen perumahan itu sendiri. Oleh karena itu, upaya pembangunan perumahan dan pemukiman terus ditingkatkan untuk menyediakan jumlah perumahan yang makin banyak dan dengan harga yang terjangkau terutama oleh golongan masyarakat yang tidak mampu membeli rumah secara tunai, maka mereka akan membeli rumah secara kredit melalui lembaga perbankan dengan mengajukan pembiayaan pemilikan rumah.

Rumah adalah kebutuhan primer bagi sebagian besar keluarga, baik yang tinggal di pedesaan maupun di perkotaan yang merupakan suatu kebutuhan primer. Pemenuhan kebutuhan primer tersebut, tidak dapat dipenuhi oleh semua orang untuk membeli secara tunai. Oleh karena itu, diperlukan suatu lembaga keuangan untuk memberikan bantuan dana dalam bentuk penyaluran kredit terutama dalam Kredit Pemilikan Rumah (KPR). ${ }^{3}$

Pesatnya pembangunan perumahan menimbulkan permasalahan lain yang sering muncul dalam pemenuhan kebutuhan akan perumahan yakni hakhak konsumen yang dirugikan. Meningkatnya pembangunan perumahan, seringkali tidak diselaraskan dengan pemenuhan kewajiban oleh pelaku usaha. Permasalahan dalam bisnis perumahan yang sering muncul adalah ketentuan mengenai pernyataan dan persetujuan untuk menerima segala persyaratan dan ketentuan-ketentuan yang ditetapkan secara sepihak dan ketentuan-ketentuan penandatanganan atas dokumen-dokumen yang telah dipersiapkan lebih awal

\footnotetext{
${ }^{2}$ Etty, Mulyati, Kredit Perbankan, PT. Refika Aditama, Bandung, 2016 hlm. 1.

${ }^{3}$ Ummuh Kalsum, Tinjauan Yuridis Terhadap Jaminan Kredit Pemilikan Rumah (KPR) Di Bni Syariah cabang mMkassar, skripsi, fakultas syariah dan hukum UIN alauddin makassar,
} 2016,hlm. 3 
PRESUMPTION of LAW

Fakultas Hukum Universitas Majalengka

Volume 2 Nomor 2 Oktober 2020

oleh pelaku usaha, tercantum dalam surat pemesanan yang sering disebut perjanjian baku atau klausula baku.

Perjanjian baku merupakan perjanjian yang hampir seluruh klausulklausulanya dibakukan oleh pemakainya dan pihak yang lain pada dasarnya tidak mempunyai peluang untuk merundingkan atau meminta perubahan ${ }^{4}$. Perjanjian baku yang selanjutnya disebut sebagai klausula baku, diadakan dengan maksud untuk mencapai tujuan efisiensi, kepastian dan lebih bersifat praktis meskipun kadang-kadang mengandung faktor negatif, karena dapat merugikan pihak lain yaitu pihak konsumen yang lemah. Pada klausula baku, konsumen dalam hal ini, hanya mempunyai dua pilihan yaitu menerima atau menolak perjanjian yang disodorkan kepadanya.

Praktik perjanjian baku sering dibuat dalam kondisi yang tidak berimbang. Produsen (Pelaku Usaha) memanipulasi perjanjian yang dibuat dalam ketentuan klausula baku. Biasanya perjanjian tersebut lebih menguntungkan salah satu pihak yaitu pelaku usaha ${ }^{5}$

Selain itu, pihak pengembang properti juga tidak jarang mencantumkan klausula baku dalam perjanjian jual beli perumahan. Klausula baku dalam bidang perumahan misalnya terdapat dalam perjanjian jual beli perumahan dalam klausula down payment (dp) atau booking fee yang menyebutkan bahwa ".....seluruh uang yang telah dibayarkan oleh pihak kedua kepada pihak kesatu menjadi hangus dan tidak dapat dituntut kembali..."

Rendahnya kesadaran dan pengetahuan konsumen, tidak mustahil dijadikan lahan bagi pelaku usaha dalam transaksi yang tidak mempunyai itikad baik dalam menjalankan usaha, yaitu berprinsip untuk mencari keuntungan yang sebesar-besarnya dengan memanfaatkan minimnya pengetahuan konsumen. ${ }^{6}$

Konsumen memiliki risiko yang lebih besar daripada pelaku usaha, dengan kata lain hak-hak konsumen sangat rentan . Disebabkan posisi tawar konsumen yang lemah, maka hak-hak konsumen sangat riskan untuk dilanggar. Posisi konsumen tersebut, harus dilindungi oleh hukum, karena salah satu sifat sekaligus tujuan hukum adalah memberikan perlindungan (pengayoman) kepada masyarakat . Perlindungan kepada masyarakat tersebut harus diwujudkan dalam bentuk kepastian hukum menjadi hak konsumen ${ }^{7}$.

Berdasarkan latar belakang permasalahan tersebut penulis tertarik untuk meneliti dan dituangkan dalam bentuk skripsi dengan judul

\footnotetext{
${ }^{4}$ Sutan Remy Sjahdeni, Kebebasan Berkontrak dan Perlindungan yang Seimbang Bagi Para Pihak dalam Perjanjian Kredit di Indonesia, Institut Bankir Indonesia, Jakarta, 1994 hlm.66

${ }^{5}$ Abdul Hakim Barkatullah, Hak-Hak Konsumen, Nusa Media, Bandung, 2010, hlm.53

6 Tiara Agustavia, Perlindungan Konsumen Terhadap Perjanjian Baku Jual Beli Perumahan, Konsentrasi Hukum Bisnis, Program Studi Ilmu Hukum, Fakultas Syariah Dan Hukum Universitas Islam Negeri Syarif Hidayatullah Jakarta, 2016, hlm. 4

${ }^{7}$ Edmon Makarim, Kompilasi Hukum Telematika, PT. Raja Grafindo Persada, Jakarta, 2003,hlm.316
} 
PRESUMPTION of LAW

Fakultas Hukum Universitas Majalengka

Volume 2 Nomor 2 Oktober 2020

"PERJANJIAN BAKU KREDIT PEMILIKAN RUMAH (KPR) PERUMAHAN DIHUBUNGKAN DENGAN PASAL 45 UNDANGUNDANG NOMOR 8 TAHUN 1999 TENTANG PERLINDUNGAN KONSUMEN

\section{B. Rumusan Masalah}

Sesuai dengan latar belakang yang diuraikan di atas, maka rumusan masalah penelitian ini ditetapkan sebagai berikut:

1. Bagaimanakah Perjanjian Baku Kredit Pemilikan Rumah berdasarkan Pasal 45 Undang-Undang Perlindungan Konsumen?

2. Upaya apa yang dilakukan oleh para pihak agar tidak ada yang dirugikan dalam Kredit Pemilikan Rumah?

\section{Tujuan Penelitian}

Sesuai dengan rumusan masalah yang dirumuskan, maka penelitian ini bertujuan untuk:

1. Untuk mengetahui dan memahami Perjanjian Baku Kredit Pemilikan Rumah berdasarkan Pasal 45 Undang-Undang Perlindungan Konsumen

2. Untuk mengetahui dan memahami upaya yang dilakukan oleh para pihak agar tidak ada yang dirugikan dalam Kredit Pemilikan Rumah

\section{Kerangka Berpikir}

Fungsi kerangka pemikiran (berpikir) dalam suatu penelitian adalah sebagai tempat yang berisikan pertimbangan-pertimbangan ilmiah terhadap penelitian yang dilaksanakan. Kerangka pemikiran dalam penelitian merupakan tulang punggung penelitian, karena di sini diuraikan landasan-landasan ilmiah atau teori yang digunakan untuk menganalisis temuan penelitian. ${ }^{8}$

Sehubungan dengan permasalahan yang telah diuraikan di atas, maka kerangka pemikiran penelitian ini menggunakan teori Negara Hukum, serta didukung dengan teori Perlindungan hukum dan teori Teori Perlindungan Konsumen

Hakikat negara hukum didasarkan pada konsep teori Kedaulatan Negara (Soeverignty) yang pada prinsipnya menyatakan kekuasaan tertinggi di dalam suatu negara adalah hukum. Seluruh alat perlengkapan negara apa pun namanya, termasuk warga negara harus tunduk dan patuh serta menjunjung tinggi hukum tanpa kecuali. Krisna Harahap mengatakan bahwa: Konsep pemikiran negara hukum seperti ini sebenarnya dapat dilihat dari awal munculnya teori Negara Hukum yang dimulai sejak abad XIX hingga abad XX.

Istilah negara hukum memang baru populer pada Abad XIX, tetapi teori Negara Hukum sebenarnya telah lama ada dan berkembang sesuai dengan tuntutan keadaan. Dimulai dari jaman Plato hingga kini, konsepsi tentang

${ }^{8}$ Sugiyono, Metode Penelitian Kuantitatif, Kualitatif dan $R \& D$, Cetakan Kesembilan, Alfabeta, Bandung, 2010, hlm. 60. 
PRESUMPTION of LAW

Fakultas Hukum Universitas Majalengka

Volume 2 Nomor 2 Oktober 2020

negara hukum banyak mengalami perubahan yang mengilhami ahli filsafat dan pakar hukum untuk merumuskan teori Negara Hukum dan hal-hal yang harus ada dalam konsep negara hukum. ${ }^{9}$

Konsep negara hukum lahir sebagai hasil perjuangan individu untuk melepaskan dirinya dari keterikatan serta tindakan sewenang-wenang penguasa. Atas dasar ini maka penguasa tidak dibenarkan melakukan tindakan sewenang-wenang kepada individu dan kekuasaannya harus pula dibatasi. Pembatasan kekuasaan dapat dilakukan melalui undang-undang atau peraturan perundang-undangan dan menurut Rukmana Amanwinata disebut dengan asas legalitas negara hukum.

Muhammad Tahir Azhary mengutip pendapat Oemar Seno Adji mengatakan bahwa: Negara Hukum Indonesia mempunyai ciri khas Indonesia, karena mempunyai pandangan hidup bernegara yaitu Pancasila. Pancasila harus diangkat sebagai dasar pokok dan sumber hukum, maka Negara Hukum Indonesia dapat pula disebut Negara Hukum Pancasila. Salah satu ciri pokok dalam Negara Hukum Pancasila adalah adanya jaminan terhadap kebebasan beragama (freedom of religion). Muhammad Tahir Azhary selanjutnya mengatakan bahwa walaupun dalam Penjelasan UUD 1945 digunakan istilah rechtstaats, tetapi yang dianut oleh Negara Indonesia bukan konsep rechtstaats dan bukan pula konsep the rule of law, melainkan konsep Negara Hukum Pancasila yang mempunyai ciri-ciri: (1) ada hubungan yang erat antara agama dan negara; (2) bertumpu pada Ketuhanan Yang Maha Esa; (3) kebebasan beragama dalam arti positif; (4) ateisme tidak dibenarkan dan komunisme dilarang; (5) asas kekeluargaan dan kerukunan. ${ }^{10}$ Dalam pendapat lain menurut Menurut Philipus M. Hadjon, ${ }^{11}$ dijelaskan bahwa ciri negara hukum Pancasila, yaitu: (1) keserasian hubungan antara pemerintah dan rakyat berdasarkan asas kerukunan; (2) hubungan fungsional yang proposional antara kekuasaankekuasaan negara; (3) prinsip penyelesaian sengketa secara musyawarah dan peradilan merupakan sarana terakhir; dan (4) keseimbangan antara hak dan kewajiban.

Sebagai pendukung teori negara hukum akan digunakan teori Perlindungan Hukum. Menurut Fitzgerald sebagaimana dikutip Satjipto Raharjo awal mula dari munculnya teori perlindungan hukum ini bersumber dari teori hukum alam atau aliran hukum alam. Aliran ini dipelopori oleh Plato, Aristoteles (murid Plato), dan Zeno (pendiri aliran Stoic). Menurut aliran hukum alam menyebutkan bahwa hukum itu bersumber dari Tuhan yang bersifat universal dan abadi, serta antara hukum dan moral tidak boleh dipisahkan. Para penganut aliran ini memandang bahwa hukum dan moral adalah cerminan dan aturan secara internal dan eksternal dari kehidupan

${ }^{9}$ Moh. Kusnardi dan Bintan Saragih, Ilmu Negara, Edisi Revisi, Cetakan Keempat, Gaya Media, Jakarta,2000, hlm. 131. Lihat juga Usep Ranawijaya, Hukum Tata Negara, Dasar-dasarnya, Ghalia, Jakarta, 1983, hlm. 181.

${ }^{10}$ Ibid, hlm. 71.

11 Philipus M. Hadjon, Perlindungan Hukum bagi Rakyat Indonesia, Bina Ilmu, Surabaya, 1987, hlm. 90. 
PRESUMPTION of LAW

Fakultas Hukum Universitas Majalengka

manusia yang diwujudkan melalui hukum dan moral. ${ }^{12}$ Fitzgerald menjelaskan teori pelindungan hukum Salmond bahwa hukum bertujuan mengintegrasikan dan mengkoordinasikan berbagai kepentingan dalam masyarakat karena dalam suatu lalu lintas kepentingan, perlindungan terhadap kepentingan tertentu hanya dapat dilakukan dengan cara membatasi berbagai kepentingan di lain pihak. Kepentingan hukum adalah mengurusi hak dan kepentingan manusia, sehingga hukum memiliki otoritas tertinggi untuk menentukan kepentingan manusia yang perlu diatur dan dilindungi. Perlindungan hukum harus melihat tahapan yakni perlindungan hukum lahir dari suatu ketentuan hukum dan segala peraturan hukum yang diberikan oleh masyarakat yang pada dasarnya merupakan kesepakatan masyarakat tersebut untuk mengatur hubungan prilaku antara anggota-anggota masyarakat dan antara perseorangan dengan pemerintah yang dianggap mewakili kepentingan masyarakat.

Penelitian ini juga mengunakan Teori Perlindungan Konsumen. Hukum perlindungan konsumen merupakan bagian dari hukum konsumen yang lebih luas $^{13}$, sehingga ruang lingkup hukum perlindungan konsumen sulit dibatasi hanya dengan menampungnya dalam satu jenis Undang-Undang, seperti Undang-Undang No. 8 Tahun 1999 tentang Perlindungan Konsumen. Hukum perlindungan konsumen selalu berhubungan dan berinteraksi dengan berbagai bidang dan cabang hukum itu senantiasa terdapat pihak yang berpredikat "konsumen". Dalam Undang - Undang No. 8 Tahun 1999 tentang Perlindungan Konsumen Pasal 1 angka 1 sendiri terdapat pengertian dari perlindungan konsumen, yaitu : "Perlindungan konsumen adalah segala upaya yang menjamin adanya kepastian hukum untuk memberi perlindungan kepada konsumen." Dari pengertian tersebut dijelaskan bahwa perlindungan konsumen adalah usaha untuk memberikan kepastian hukum kepada konsumen dengan cara memberikan kepastian kepada setiap konsumen. Penjelasan mengenai konsumen juga diatur dalam Undang - Undang Perlindungan Konsumen Pasal 1 angka 2, yaitu : "Konsumen adalah setiap orang pemakai barang dan/atau jasa yang tersedia dalam masyarakat, baik bagi kepentingan diri sendiri, keluarga, orang lain, maupun makhluk hidup lain dan tidak untuk di perdagangkan." Dengan memahami pengertian perlindungan konsumen dan konsumen, maka perbedaan hukum antara konsumen dan perlindungan konsumen, antara hak-hak pokok dari konsumen dan keterkaitan hukum perlindungan konsumen dengan bidang-bidang hukum yang lain dapat memberikan gambaran menyeluruh tentang hukum perlindungan konsumen.

\section{E. Metode Penelitian}

Metode penelitian yang digunakan dalam penelitian ini adalah deskriptif analisis yaitu penelitian yang menggambarkan peraturan perundang-undangan yang berlaku dikaitkan dengan teori-teori hukum positif yang menyangkut permasalahan yang sedang diteliti dan pendekatan yang digunakan dalam

${ }^{12}$ Satjipto Raharjo, Ilmu Hukum, PT. Citra Aditya Bakti, Bandung, 2000, hlm.53.

13 Celina Tri Siwi Kristiyanti, Hukum Perlindungan Konsumen, Sinar Grafika, Jakarta,2018, hlm.13 
PRESUMPTION of LAW

Fakultas Hukum Universitas Majalengka

Volume 2 Nomor 2 Oktober 2020

penelitian ini adalah pendekatan yuridis normatif, yaitu dengan mengkaji atau menganalisis data sekunder yang berupa bahan-bahan hukum sekunder dengan memahami hukum sebagai perangkat peraturan atau norma-norma positif di dalam sistem perundang-undangan yang mengatur mengenai permasalahan dalam penelitian ini. Jadi penelitian ini dipahami sebagai penelitian kepustakaan, yaitu penelitian terhadap data sekunder. Setelah data sekunder dan primer terkumpul, kemudian diadakan analisis secara kualitatif yaitu menganalisis data berupa uraian-uraian yang sistematis tanpa mempergunakan bagan-bagan dan rumus statistik.

\section{F. Hasil Penelitian dan Pembahasan}

\section{Perjanjian Baku Kredit Pemilikan Rumah berdasarkan Pasal 45 Undang-Undang Perlindungan Konsumen}

Pada masa sekarang ini perjanjian atau kontrak antara pelaku usaha dengan konsumen hampir selalu menggunakan perjanjian atau kontrak yang berbentuk standar atau baku, perjanjian atau kontrak semacam ini dinamakan perjanjian atau kontrak baku.

Hondius mengemukakan latar belakang sejarah timbulnya perjanjian baku. Ia mengemukakan bahwa model kontrak baku telah mempunyai sejarah ribuan tahun. Ketika lima ribu tahun yang lalu di Mesir dan Negara Dua Sungai dibuat tulisan-tulisan pertama, hampir pada saat yang sama muncul syarat-syarat kontrak yang dibakukan pertama kali. Sesudah itu dibanyak peradaban ada gejala untuk melepaskan formalisma dari modelmodel kontrak yang ditetapkan oleh para rohaniawan ${ }^{14}$.

Gras dan Pitlo juga mengemukakan latar belakang lahirnya perjanjian baku. Gras mengatakan bahwa kelahiran perjanjian baku antara lain merupakan akibat dari perubahan susunan masyarakat. Masyarakat sekarang bukan lagi kumpulan individu seperti pada abad XIX, akan tetapi merupakan kumpulan dari sejumlah ikatan kerja sama (organisasi). Perjanjian bakulazimnya diperbuat oleh organisasi perusahaan-perusahaan. Pitlo berkata pula bahwa latar belakang tumbuhnya perjanjian baku adalah keadaan social dan ekonomi. Perusahaan yang besar, perusahaan semi pemerintah atau perusahaan-perusahaan pemerintah mengadakan kerja sama dalam suatu organisasi dan untuk kepentingan mereka menentukan syaratsyarat tertentu secara sepihak. Pihak lawannya (waderpartij) yang pada umumnya mempunyai kedudukan (ekonomi) lemah, baik karena posisinya maupun karena ketidaktahuaanya hanya menerima apa yang disodorkan itu. $^{15}$

Kontrak standar atau kontrak baku adalah kontrak berbentuk tertulis yang telah digandakan berupa formulir-formulir, yang isinya telah distandarisasikan atau dibakukan terlebih dahulu secara sepihak oleh pihak

\footnotetext{
${ }^{14}$ Satria Mega Nurcahya, Kajian Yuridis Asas Kebebasan Berkontrak Dan Perlindungan Konsumen Pada Perjanjian Kredit Pemilikan Rumah (KPR), Skripsi, Fakultas Hukum Universitas Atma Jaya Yogyakarta 2015, hlm 33

${ }^{15}$ Salim H.S dan Erlies Septiana Nurbani, Perkembangan Hukum Kontrak Innominat di Indonesia, Cet 1, Sinar Grafika, Jakarta, 2014,hlm 101
} 
PRESUMPTION of LAW

Fakultas Hukum Universitas Majalengka

Volume 2 Nomor 2 Oktober 2020

yang menawarkan, dalam hal ini pelaku usaha dan ditawarkan secara masal tanpamempertimbangkan perbedaan kondisi yang dimiliki konsumen. ${ }^{16}$ Munir Fuady merumuskan perjanjian baku sebagai berikut :

"Suatu kontrak tertulis yang dibuat oleh salah satu pihak dalam kontrakyang sudah tercetak dalam bentuk formulir, yang ketika ditandatangani umumnya para pihak hanya mengisikan data-data informatif tertentu dengan sedikit atau tanpa perubahan dalam klausulklausulnya, dimana pihak lain dalam kontrak tersebut tidak mempunyai atau hanya sedikit kesepakatan untuk menegoisasi klausula-klausula yang sudah dibuat olehsalah satu pihak tersebut, sehingga biasanya kontrak baku sangat beratsebelah."17

Sedangkan pada masa sekarang ini perjanjian kredit yang umum ditemukan dalam masyarakat menggunakan bentuk perjanjian baku atau perjanjian standar. Pada dasarnya perjanjian baku adalah konsep janji-janji tertulis. Disusun tanpa membicarakan isinya dan lazimnya dituangkan ke dalam sejumlah tak terbatas perjanjian yang sifatnya tertentu. Perjanjian baku juga merupakan perjanjian yang isinya dibakukan dan dituangkan dalam bentuk formulir.

Perjanjian kredit sendiri merupakan perjanjian konsensuil antara debitur dengan kreditur (dalam hal ini Bank) yang melahirkan hubungan hutang piutang, dimana debitur berkewajiban membayar kembali pinjaman yang diberikan oleh kreditur, dengan berdasarkan syarat-syarat dan kondisi yang telah disepakati oleh masing-masing pihak yaitu antara debitur dan kreditur.

Penggunaan perjanjian baku ini sudah lazim dimasyarakat karena untuk menghemat biaya dan waktu dalam pencairan kredit. Dan biasanya syarat-syarat maupun isi klausula yang penting sudah tersusun dan pihak yang membutuhkan atau debitur hanya perlu melengkapi identitas saja.

Inti dari perjanjian baku menurut Hondius adalah bahwa isi perjanjian itu tanpa dibicarakan dengan pihak lainnya, sedangkan pihak lainnya hanya diminta untuk menerima atau menolak isinya. Mariam Badrulzaman mengemukakan bahwa standar contract merupakan perjanjian yang telah dibakukan. Mariam Darus Badrulzaman juga mengemukakan ciri-ciri perjanjian baku. Ciri perjanjian baku yaitu :

a. Isinya ditetapkan secara sepihak oleh pihak yang posisi ekonominya kuat.

b. Masyarakat (debitur) sama sekali tidak ikut bersama-sama menetukan isi perjanjian.

c. Terdorong oleh kebutuhannya debitur terpaksa menerima perjanjian itu.

${ }^{16}$ Johannes Gunawan, Tanggung Jawab Pelaku Usaha Menurut UU No.8 tahun 1999 tentang Perlindungan Konsumen, Jurnal Hukum Bisnis, Yayasan Pengembangan Hukum Bisnis, Jakarta, 1999,hlm 46

${ }_{17}$ Munir Fuady, Hukum Kontrak dari Sudut Pandang Hukum Bisnis, cet 1, Citra Aditya Bakti, Bandung, 2003, hlm 76 
PRESUMPTION of LAW

Fakultas Hukum Universitas Majalengka

Volume 2 Nomor 2 Oktober 2020

d. Bentuk tertentu (tertulis).

e. Dipersiapkan secara masal dan kolektif. ${ }^{18}$

Sedangkan didalam hukum kontrak sendiri dikenal adanya lima asas penting, yaitu asas kebebasan berkontrak, asas konsensualisme, asas pacta sunt servanda (asas kepastian hukum), asas iktikad baik, dan asas kepribadian.

Asas konsensualimse dapat disimpulkan dalam Pasal 1320 ayat (1) KUHPerdata. Dalam pasal itu ditentukan bahwa salah satu syarat sahnya perjanjian yaitu adanya kesepakatan kedua belah pihak. Asas konsensualisme merupakan asas yang menyatakan bahwa perjanjian pada umumnya tidak diadakan secara formal, tetapi cukup dengan adanya kesepakatan kedua belah pihak. Asas pacta sun servanda merupakan asas bahwa hakim atau pihak ketiga harus menghormati substansi kontrak yang dibuat oleh para pihak, sebagaimana layaknya sebuah undang-undang. Mereka tidak boleh melakukan intervensi terhadap substansi kontrak yang dibuat oleh para pihak.

Asas itikad baik dapat disimpulkan dari Pasal 1338 ayat (3) KUHPerdata yang berbunyi "perjanjian harus dilaksanakan dengan iktikad baik." Asas ini merupakan asas bahwa para pihak, yaitu pihak kreditur dan debitur harus melaksanakan substansi kontrak berdasarkan kepercayaan atau keyakinan yang teguh atau kemauan baik dari para pihak.

Asas kepribadian merupakan asas yang menentukan bahwa seseorang akan melakukan dan atau membuat kontrak hanya untuk kepentingan perseorangan saja. Hal ini dapat dilihat dalam Pasal 1315 dan Pasal 1340 KUHPerdata. Namun ketentuan itu ada pengecualiannya, sebagaimana yang dintrodusir dalam Pasal 1317 KUHPerdata.

Asas kebebasan berkontrak dapat dianalisis dari ketentuan Pasal 1338 ayat (1) KUHPerdata. Asas kebebasan berkontrak adalah suatu asas yang memberikan kebebasan kepada para pihak untuk membuat atau tidak membuat perjanjian, mengadakan perjanjian, menetukan isi, pelaksanaan, dan persyaratan perjanjian, menetukan bentuknya perjanjian.

Kemudian latar belakang lahirnya asas kebebasan berkontrak sendiri adalah adanya paham individualisme yang secara embrional lahir dalam zaman Yunani, yang diteruskan oleh kaum Epicuristen dan berkembang pesat dalam zaman renaissance melalui antara lain ajaran-ajaran Hugo de Grecht, Thomas Hobbes, Jhon Locke, dan Rosseau. Menurut paham individualisme, setiap orang bebas untuk memperoleh apa yang dikehendakinya. Dalam hukum kontrak asas ini diwujudkan dalam "kebebasan berkontrak". 19

Dalam Undang-undang Dasar 1945 dan KUHPerdata Indonesia dan perundang-undangan lain tidak ada ketentuan yang secara tegas menentukan

18 Salim H.S dan Erlies Septiana Nurbani, Op. Cit., hlm 100

${ }^{19}$ Salim H.S, Hukum Kontrak Teori dan Teknik Penyusunan Kontrak, Sinar Grafika, Jakarta, 2003, hlm 9 
PRESUMPTION of LAW

Fakultas Hukum Universitas Majalengka

Volume 2 Nomor 2 Oktober 2020

tentang berlakunya asas kebebasan berkontrak bagi perjanjian-perjanjian yang dibuat menurut hukum Indonesia.

Pasal 1338 KUHPerdata, menyatakan bahwa semua kontrak atau perjanjian yang dibuat secara sah berlaku sebagai undang-undang bagi mereka yang membuatnya. Kata "semua" dalam Pasal tersebut mengindikasikan bahwa orang dapat membuat perjanjian apa saja, tidak terbatas pada jenis perjanjian yang diatur dalam KUHPerdata, dan perjanjian tersebut akan mengikat para pihak yang membuatnya. Pasal 1338 KUHPerdata itu sendiri juga menggunakan kalimat "yang dibuat secara sah", hal ini berarti bahwa apa yang disepakati antara para pihak, berlaku sebagai undang-undang selama apa yang disepakati itu adalah sah. Artinya tidak bertentangan dengan undang-undang, ketertiban umum, dan kesusilaan. Dalam hal suatu kontrak ternyata bertentangan dengan undangundang, ketertiban umum, dan kesusilaan, kontrak tersebut batal demi hukum.

Menurut hukum perjanjian Indonesia seseorang bebas untuk membuat perjanjian dengan pihak manapun yang dikehendakinya. Undang-Undang hanya mengatur orang-orang tertentu yang tidak cakap untuk membuat perjanjian, pengaturan mengenai hal ini dapat dilihat dalam Pasal 1330 Kitab Undang-Undang Hukum Perdata. Dari ketentuan ini dapat disimpulkan bahwa setiap orang bebas untuk memilih pihak yang ia inginkan untuk membuat perianjian, asalkan pihak tersebut bukan pihak yang tidak cakap. Bahkan lebih lanjut dalam Pasal 1331, ditentukan bahwa andaikatapun seseorang membuat perjianjian dengan pihak yang dianggap tidak cakap menurut Pasal 1330 KUH Perdata tersebut, maka perjanjian itu tetap sah selama tidak dituntut pembatalannya oleh pihak yang tidak cakap.

Apabila dilihat lebih lanjut perjanjian Kredit Pemilikan Rumah (KPR) antara lembaga perbankan dengan konsumen tersebut dikaitkan dengan asas kebebasan berkontrak,jika dilihat dari segi hukum di Indonesia bisa dilihat seperti pada Pasal 1338 KUHPerdata. Dalam pasal tersebut perjanjian yang dibuat dalam bentuk perjanjian baku dapat dikatakan sah karena para pihak menyetujui, tetapi dalam hal ini para pihak menyetujui karena terdorong oleh adanya kebutuhan. Hal ini juga diperkuat dalam Pasal 1320 KUHPerdata dimana suatu kontrak atau perjanjian harus memenuhi syarat sahnya perjanjian, yaitu kata sepakat, kecakapan, hal tertentu dan suatu sebab yang halal. Jika dilihat dengan kaitanya Undang-Undang Perlindungan Konsumen hak-hak debitur sudah terlindungi karena adanya pembatasan dalam pencantuman klausula baku yang terdapat dalam Pasal 18 UUPK dan apabila hal itu dilanggar maka akan batal demi hukum. Pada dasarnya UUPK tidak melarang pelaku usaha untuk membuat perjanjian yang memuat klausul baku, asal tidak berbentuk sebagaimana yang dilarang dalam Pasal 18 UUPK. Apabila terjadi pelanggaran atas Pasal 18 UUPK tersebut, maka klausul baku tersebut batal demi hukum, tetapi tidak berarti batalnya perjanjian secara keseluruhan. Pelaku usaha diwajibkan menyesuaikan isi perjanjian baku dengan ketentuan Pasal 18 UUPK. Selain berlaku ketentuan UUPK, terhadap perjanjian baku berlaku pula ketentuan- 
PRESUMPTION of LAW

Fakultas Hukum Universitas Majalengka

Volume 2 Nomor 2 Oktober 2020

ketentuan yang berlaku dalam Buku III Kitab Undang-Undang Hukum Perdata (KUH Perdata), khususnya tentang syarat sahnya perjanjian (Pasal 1320 KUH Perdata). Namun apabila konsumen merasa dirugikan dapat menggugat pelaku usaha. Begitu pula menurut Pasal 45 UUPK setiap konsumen yang dirugikan dapat menggugat pelaku usaha melalui lembaga yang bertugas menyelesaikan sengketa antara konsumen dan pelaku usaha atau melalui peradilan yang berada di lingkungan peradilan umum.

Penyelesaian sengketa konsumen tersebut dapat ditempuh melalui pengadilan atau diluar pengadilan berdasarkan pilihan sukarela para pihak yang bersengketa. Konsumen dapat menggugat pelaku usaha di peradilan umum secara perorangan atau secara berkelompok (class action). Gugatan terhadap pelaku usaha tersebut juga dapat diajukan oleh lembaga perlindungan konsumen swadaya masyarakat dan pemerintah dan/atau instansi terkait apabila barang dan/atau jasa yang dikonsumsi atau dimanfaatkan mengakibatkan kerugian materi yang besar dan/atau korban yang tidak sedikit.

Selain penyelesaian melalui pengadilan, UUPK memberikan alternatif cara menyelesaikan sengketa konsumen melalui jalur di luar pengadilan (non litigasi) yaitu melalui Badan Penyelesaian Sengketa Konsumen (BPSK). Tugas dan wewenang BPSK sebagaimana diatur dalam Pasal 52 UUPK dan Keputusan Menteri Perindustrian dan Perdagangan Nomor. 350/MPP/Kep/12/2001 tanggal 10 Desember 2001 tentang Pelaksanaan Tugas dan Wewenang Badan Penyelesaian Sengketa Konsumen yaitu melaksanakan penanganan dan penyelesaian sengketa konsumen dengan cara konsiliasi, mediasi dan arbitrase dan memberikan konsultasi perlindungan konsumen.

Keanggotaan Majelis BPSK terdiri dari unsur pemerintah, pelaku usaha dan konsumen. Pada dasarnya konsumen dapat langsung menuntut ganti rugi kepada pelaku usaha, namun apabila pelaku usaha tersebut menolak atau tidak memberi tanggapan atas tuntutan ganti rugi tersebut maka konsumen dapat menggugat pelaku usaha yang bersangkutan ditempat kedudukan konsumen.Jika konsumen memilih upaya penyelesaian sengketa konsumen diluar pengadilan, gugatan melalui pengadilan hanya dapat ditempuh apabila upaya tersebut dinyatakan tidak berhasil oleh salah satu pihak atau oleh para pihak yang bersengketa.

\section{Upaya yang dilakukan oleh para pihak agar tidak ada yang dirugikan dalam Kredit Pemilikan Rumah}

Pasal 1233 KUH Perdata mengatur bahwa tiap-tiap perikatan dilahirkan baik karena perjanjian maupun karena undang-undang, sehingga dengan perbedaan tersebut juga telah membedakan akibat hukum antara hubungan hukum yang lahir karena perjanjian dan hubungan hukum yang lahir karena undang-undang.

Akibat hukum suatu perikatan yang lahir dari perjanjian memang dikehendaki oleh para pihak, karena memang perjanjian didasarkan atas kesepakatan, yaitu persesuaian kehendak antara para pihak yang membuat 
PRESUMPTION of LAW

Fakultas Hukum Universitas Majalengka

Volume 2 Nomor 2 Oktober 2020

perjanjian. Sedangkan akibat hukum suatu perikatan yang lahir dari undangundang mungkin tidak dikehendaki oleh para pihak, tetapi hubungan hukum dan akibat hukumnya telah ditentukan oleh undang-undang, baik ketentuan hukum yang diatur di dalam KUHPerdata maupun norma-norma hukum yang tersebar di luar KUHPerdata yang bersifat hukum publik, namun pengaturannya bersifat keperdataan.

Salah satu norma hukum yang mengatur hubungan hukum di luar ketentuan KUHPerdata yaitu norma-norma hukum yang diatur dalam Undang-Undang Perumahan dan Permukiman serta Undang-Undang Nomor 8 Tahun 1999 tentang Perlindungan Konsumen (UUPK).

Dalam kaitannya dengan perlindungan hukum bagi konsumen, di dalam UUPK telah diatur berbagai norma-norma hubungan hukum antara konsumen dengan pelaku usaha. Norma-norma hubungan hukum dalam UUPK ini telah memberikan kedudukan yang seimbang antara pelaku usaha dan konsumen. Norma-norma tersebut sekaligus merupakan norma-norma perlindungan kepada konsumen dalam hubungan hukum dengan pelaku usaha, yang menurut Yusuf Shofie ${ }^{20}$ dikelompokkan sebagai berikut:

a. Kegiatan produksi dan/atau perdagangan barang dan/atau jasa;

b. Kegiatan penawaran, promosi, dan periklanan barang dan/atau jasa;

c. Kegiatan transaksi penjualan barang dan/atau jasa;

d. Kegiatan pasca transaksi penjualan barang dan/atau jasa.

Dalam hubungan hukum jual beli dan pemanfaatan rumah tinggal antara konsumen dan pelaku usaha, pengelompokan norma-norma tersebut tercermin dalam setiap tahapan atau proses hubungan hukum, yang meskipun hubungan hukum jual beli rumah tinggal antara konsumen dan pelaku usaha didasarkan pada suatu perjanjian (perjanjian jual beli), namun ketentuan-ketentuan di dalam Undang-Undang Perumahan dan Permukiman serta UUPK tidak dapat dikesampingkan begitu saja sebagai norma-norma hukum perikatan yang lahir dari undang-undang yang berlaku sebagai hukum publik.

Hubungan hukum jual beli rumah tinggal antara konsumen dan pelaku usaha merupakan salah satu objek kajian hukum perikatan dengan persoalan hukum yang sangat kompleks, yang tidak hanya terjadi pada skala nasional tetapi juga sudah menjadi persoalan pada masing-masing daerah di mana lokasi permukiman dikembangkan oleh pelaku usaha. Oleh karena itu memerlukan suatu perlindungan hukum baik bagi konsumen maupun bagi pelaku usaha agar kedua belah pihak merasa tidak dirugikan

Perlindungan konsumen adalah segala upaya yang menjamin adanya kepastian hukum untuk memberi perlindungan hukum kepada konsumen (Pasal 1 angka (1) UUPK). Perlindungan hukum merupakan perlindungan atas hak-hak konsumen baik dari pelaku usaha, pemerintah serta institusi

${ }^{20}$ Muhammad Anies, Perlindungan Hukum Bagi Konsumen Atas Pemilikan Rumah Dari Developer Di Kota Makassar, jurnal Fakultas Syariah dan Hukum UIN Alauddin Vol. 5 / No. 2 / Desember, Makassar 2016, hlm 275 
PRESUMPTION of LAW

Fakultas Hukum Universitas Majalengka

Volume 2 Nomor 2 Oktober 2020

hukum dalam kaitannya dengan pemanfaatan atau penggunaan suatu produk barang dan/atau jasa, baik berdasarkan perjanjian maupun menurut peraturan perundang-undangan yang berlaku untuk memberikan jaminan kepastian hukum kepada konsumen sesuai asas perlindungan konsumen. Untuk mewujudkan perlindungan bagi konsumen, maka perlindungan konsumen diselenggarakan sebagai usaha bersama berdasarkan 5 (lima) asas yang relevan dalam pembangunan nasional (penjelasan Pasal 2 UUPK), yaitu:

a. Asas manfaat dimaksudkan untuk mengamanatkan bahwa segala upaya dalam penyelenggaran perlindungan konsumen harus memberikan manfaat sebesarbesarnya bagi kepentingan konsumen dan pelaku usaha secara keseluruhan;

b. Asas keadilan dimaksudkan agar partisipasi seluruh rakyat dapat diwujudkan secara maksimal dan memberikan kesempatan kepada kosnumen dan pelaku usaha untuk memperoleh haknya dan melaksanakan kewajibannya secara adil;

c. Asas keseimbangan dimaksudkan untuk memberikan keseimbangan antara kepentingan konsumen, pelaku usaha, pemerintah dalam arti materil ataupun spritual;

d. Asas keamanan dan keselamatan konsumen dimaksudkan untuk memberikan jaminan atas keamanan dan keselamatan kepada konsumen dalam penggunaan, pemakaian, dan pemanfaatan barang dan/atau jasa yang dikonsumsi atau digunakan;

e. Asas kepastian hukum dimaksudkan agar baik pelaku usaha maupun konsumen menaati hukum dan memperoleh keadilan dalam penyelenggaraan perlindungan konsumen, serta negara menjamin kepastian hukum

Dalam hubungan pemilikan rumah dari pelaku usaha, perlindungan hukum ini dimaksudkan untuk memberikan perlindungan dalam hubungan hukum jual beli dan pemilikan rumah serta perlindungan terhadap hak-hak konsumen untuk menikmati dan memanfaatkan segala sesuatu yang seharusnya diperoleh dalam kaitan jual beli rumah dari developer atau pelaku usaha

Perlindungan hukum bagi konsumen dalam pemilikan rumah ini juga meliputi perlindungan terhadap pengaduan konsumen sebagai akibat telah terjadinya pelanggaran hak-hak individual konsumen (seperti mutu bangunan di bawah standar, ukuran luas tanah tidak sesuai dan lain-lain), serta pelanggaran hak-hak kolektif konsumen (seperti tidak dibangunnya fasum dan/atau fasos, sertifikasi, rumah fiktif, banjir dan kebenaran informasi dalam iklan, brosur atau sarana promosi lainnya).

Perlindungan hukum atas hak-hak konsumen di atas, harus diperoleh tiap-tiap konsumen pada setiap proses tahapan transaksi, baik pada tahap pratransaksi (sejak awal proses produksi), tahap transaksi (proses jual beli) maupun pada tahap purna/pascatransaksi (pemanfaatan dan penggunaan 
PRESUMPTION of LAW

Fakultas Hukum Universitas Majalengka

Volume 2 Nomor 2 Oktober 2020

rumah tinggal). Perlindungan hukum dalam setiap tahapan transaksi tersebut selanjutnya menjadi norma-norma perlindungan bagi konsumen.

Senada dengan paparan di atas, agar para pihak tidak ada yang dirugikan dalam kredit pemilikan rumah, artinya konsumen dan pelaku usaha merupakan pihak-pihak yang harus mendapat perlindungan hukum. Namun, posisi konsumen pada umumnya lemah dibandingkan dengan pelaku usaha. Hal ini berkaitan dengan tingkat kesadaran akan haknya, kemampuan financial dan daya tawar (bargaining position) yang rendah. Padahal tata hukum tidak bisa mengandung kesenjangan. Tata hukum harus memposisikan pada tempat yang adil dimana hubungan konsumen dengan pelaku usaha berada pada kedudukan yang saling menghendaki dan mempunyai tingkat ketergantungan yang cukup tinggi satu dengan yang lain.

Posisi konsumen harus dilindungi oleh hukum, karena salah satu sifat dan tujuan hukum adalah memberikan perlindungan (pengayoman) kepada masyarakat. Perlindungan hukum kepada masyarakat tersebut harus diwujudkan dalam bentuk kepastian hukum yang menjadi hak konsumen. Jika kita kaitkan dengan teori kepastian hukum, maka kepastian hukum dimaknai bahwa seseorang akan dapat memperoleh suatu yang diharapkan dalam keadaan tertentu. Kepastian hukum diartikan sebagai norma sehingga dapat dijadikan pedoman bagi masyarakat. ${ }^{21}$

\section{G. Kesimpulan}

1. Perjanjian baku kredit pemilikan rumah apabila merugikan konsumen. Konsumen dapat menggugat pelaku usaha. Begitu pula menurut Pasal 45 UUPK setiap konsumen yang dirugikan dapat menggugat pelaku usaha melalui lembaga yang bertugas menyelesaikan sengketa antara konsumen dan pelaku usaha atau melalui peradilan yang berada di lingkungan peradilan umum. Penyelesaian sengketa konsumen tersebut dapat ditempuh melalui pengadilan atau diluar pengadilan berdasarkan pilihan sukarela para pihak yang bersengketa. Konsumen dapat menggugat pelaku usaha di peradilan umum secara perorangan atau secara berkelompok (class action).

2. Agar para pihak tidak ada yang dirugikan dalam kredit pemilikan rumah, maka harus ada perlindungan hukum dalam bertransaksi kredit pemilikan rumah dan harus ada bentuk perlindungan hukum terhadap para pihak dalam bertransaksi elektronik sehingga apabila dilanggar maka dapat mengajukan gugatan dari pada para pihak yang merasa dirugikan .

${ }^{21}$ Wijayanti, Asas Kepastian Hukum, Keadilan dan Kemanfaatan Dalam Kaitannya Dengan Keputusan Kepailitan Niaga, Vol.14 No.2 Tahun 2014, hlm. 219 
PRESUMPTION of LAW

Fakultas Hukum Universitas Majalengka

Volume 2 Nomor 2 Oktober 2020

\section{H. Saran}

1. Undang-Undang Perlindungan Konsumen Nomor 8 Tahun 1999 (UUPK) harus lebih disosialisasikan oleh aparat penegak hukum, sebagai aturan yang efektif untuk menyelesaikan sengketa konsumen, seperti sengketa konsumen perumahan.

2. Bagi para pihak yang tidak melaksanakan tanggung jawabnya sesuai dengan perjanjian yang telah disepakati bersama, dapat digugat perdata oleh pihak yang dirugikan untuk memperoleh pembayaran ganti rugi sebagaimana yang diatur dalam hukum positf. 
PRESUMPTION of LAW

Fakultas Hukum Universitas Majalengka

Volume 2 Nomor 2 Oktober 2020

\section{DAFTAR PUSTAKA}

\section{A. Sumber buku}

Abdul Hakim Barkatullah, Hak-Hak Konsumen, Nusa Media, Bandung, 2010.

Celina Tri Siwi Kristiyanti, Hukum Perlindungan Konsumen, Sinar Grafika, Jakarta,2018.

Edmon Makarim, Kompilasi Hukum Telematika, PT. Raja Grafindo Persada, Jakarta, 2003.

Etty, Mulyati, Kredit Perbankan, PT. Refika Aditama, Bandung, 2016.

Moh. Kusnardi dan Bintan Saragih, Ilmu Negara, Edisi Revisi, Cetakan Keempat, Gaya Media, Jakarta,2000.

Munir Fuady, Hukum Kontrak dari Sudut Pandang Hukum Bisnis, cet 1, Citra Aditya Bakti, Bandung, 2003.

Philipus M. Hadjon, Perlindungan Hukum bagi Rakyat Indonesia, Bina Ilmu, Surabaya, 1987.

Salim H.S dan Erlies Septiana Nurbani, Perkembangan Hukum Kontrak Innominat di Indonesia, Cet 1, Sinar Grafika, Jakarta, 2014.

Salim H.S, Hukum Kontrak Teori dan Teknik Penyusunan Kontrak, Sinar Grafika, Jakarta, 2003.

Satjipto Raharjo, Ilmu Hukum, PT. Citra Aditya Bakti, Bandung, 2000.

Sugiyono, Metode Penelitian Kuantitatif, Kualitatif dan $R \& D$, Cetakan Kesembilan, Alfabeta, Bandung, 2010.

Sutan Remy Sjahdeni, Kebebasan Berkontrak dan Perlindungan yang Seimbang Bagi Para Pihak dalam Perjanjian Kredit di Indonesia, Institut Bankir Indonesia, Jakarta, 1994 .

Usep Ranawijaya, Hukum Tata Negara, Dasar-dasarnya, Ghalia, Jakarta, 1983.

\section{B. Peraturan Perundang-undangan}

Undang-Undang Dasar Negara Republik Indonesia Tahun 1945.

Kitab Undang-Undang Hukum Perdata 
PRESUMPTION of LAW

Fakultas Hukum Universitas Majalengka

Volume 2 Nomor 2 Oktober 2020

Undang-Undang Republik Indonesia Nomor 8 Tahun 1999, Tentang UndangUndang Perlindungan Konsumen

Undang-Undang Nomor 4 Tahun 1992 tentang Perumahan dan Pemukiman

\section{Sumber Lain}

Johannes Gunawan, Tanggung Jawab Pelaku Usaha Menurut UU No.8 tahun 1999 tentang Perlindungan Konsumen, Jurnal Hukum Bisnis, Yayasan Pengembangan Hukum Bisnis, Jakarta, 1999.

Muhammad Anies, Perlindungan Hukum Bagi Konsumen Atas Pemilikan Rumah Dari Developer Di Kota Makassar, jurnal Fakultas Syariah dan Hukum UIN Alauddin Vol. 5 / No. 2 / Desember, Makassar 2016.

Satria Mega Nurcahya, Kajian Yuridis Asas Kebebasan Berkontrak Dan Perlindungan Konsumen Pada Perjanjian Kredit Pemilikan Rumah $(K P R)$, Skripsi, Fakultas Hukum Universitas Atma Jaya Yogyakarta 2015.

Tiara Agustavia, Perlindungan Konsumen Terhadap Perjanjian Baku Jual Beli Perumahan, Konsentrasi Hukum Bisnis, Program Studi Ilmu Hukum, Fakultas Syariah Dan Hukum Universitas Islam Negeri Syarif Hidayatullah Jakarta, 2016.

Ummuh Kalsum, Tinjauan Yuridis Terhadap Jaminan Kredit Pemilikan Rumah (KPR) Di Bni Syariah cabang mMkassar, skripsi, fakultas syariah dan hukum UIN alauddin makassar, 2016.

Wijayanti, Asas Kepastian Hukum, Keadilan dan Kemanfaatan Dalam Kaitannya Dengan Keputusan Kepailitan Niaga, Vol.14 No.2 Tahun 2014. 